\title{
Balungan Ladrang Slamet Laras Slendro Pathet Manyura Ditinjau dari Konsep Mancapat
}

\author{
Indah Ayu Fitria ${ }^{1}$ \\ Jurusan Karawitan, Institut Seni Indonesia Yogyakarta
}

\begin{abstract}
Balungan Ladrang Slamet of the Slendro Pathet Manyura Reviewed from the Mancapat Concept. Ladrang Slamet for traditional Javanese people seems to be as a genre of prayer for salvation. However, interestingly, in Ladrang Slamet there are no poems that explicitly refer to matters relating to salvation. Even the poetry used is cakepan salisir, which is also often used in other songs. The study wants to discuss the meaning of salvation in Ladrang Slamet, which is assumed found in the arrangement of the notes. The structural analysis which is based on the Mancapat concept with a mythological approach is used to describe the structure of balungan Ladrang Slamet, the harmony of slendro pathet manyura. Through this analysis, it was concluded that the structure of Ladrang Slamet is a manifestation of the system of relations of the gods, namely Shiva-Kama-Brahma-Narada which in the relationship shows Shiva's capacity as a source of power that governs time in achieving perfection.
\end{abstract}

Keywords: ladrang slamet; balungan; mancapat

\begin{abstract}
ABSTRAK
Ladrang Slamet bagi masyarakat Jawa tradisonal rupa-rupanya telah dipandang sebagai gending doa keselamatan. Namun, menariknya di dalam Ladrang Slamet tidak dijumpai syair yang secara eksplisit merujuk pada hal-hal yang berkenaan dengan keselamatan. Bahkan syair yang digunakan adalah cakepan salisir, yang juga sering digunakan pada gending-gending yang lain. Merujuk pada permasalahan di atas, studi ini ingin menjawab pertanyaan tentang pemaknaan keselamatan dalam Ladrang Slamet yang diasumsikan terletak pada susunan nada-nadanya. Analisis struktural yang berpijak pada konsep Mancapat dengan pendekatan mitologi digunakan untuk menguraikan struktur balungan Ladrang Slamet laras slendro pathet manyura. Melalui analisis tersebut diperoleh kesimpulan bahwa struktur Ladrang Slamet merupakan manifestasi dari sistem relasi dewa-dewa, yakni Siwa-Kama-Brahma-Narada yang mana dalam hubungan relasinya menunjukkan kapasitas Siwa sebagai sumber kekuatan yang mengatur waktu dalam mencapai kesempurnaan.
\end{abstract}

Kata kunci: ladrang slamet; balungan; mancapat

\section{Pendahuluan}

Ladrang Slamet atau juga dikenal dengan Ladrang Wilujeng merupakan salah satu gending yang populer di kalangan masyarakat Jawa. Gending ini hampir sering dimainkan pada setiap pertunjukan uyon-uyon, serta lazim digunakan sebagai sebuah ungkapan do'a pengharapan keselamatan. Beberapa diantaranya sebagai gending pembuka pertunjukan wayang atau bahkan upacara adat mantenan (Saptono, 2005). Hal demikian sesuai dengan terminologi Ladrang Slamet sendiri, oleh karena itu logikanya di dalam Ladrang Slamet terdapat cakepan-cakepan yang berisikan tentang do'a keselamatan.

Pada dasarnya ada beberapa gending yang secara eksplisit mengungkapkan permohonan keselamatan. Di antaranya adalah Ladrang

\footnotetext{
Alamat korespondensi: Jurusan Karawitan Fakultas Seni Pertunjukan ISI Yogyakarta. E-mail: indahayufitria@ gmail.com.
} 
Mugi Rahayu, dalam gending ini secara eksplisit permohonan keselamatan diungkapkan melalui cakepan gawan yang cakepannya merujuk pada nama gending (bandingkan dengan (Suyoto, Timbul Haryono, 2015). Do'a keselamatan pada ladrang ini ditunjukkan pada cakepan senggakan gerongannya yang berbunyi "mugi rahayu $a$ ". Selain itu, ungkapan do'a keselamatan juga tertuang pada cakepan gerongan Ketawang Pamuji yang berbunyi "Hong awignam astu nama, mugi rahayua sagung dumadi". Dari gending-gending keselamatan tersebut, Ladrang Slamet menjadi gending keselamatan yang memiliki keunikan tersendiri. Hal demikian dikarenakan cakepan yang digunakan dalam Ladrang Slamet adalah cakepan Salisir atau cakepan Salisir Puspagiwang. Adapun cakepan Salisir adalah sebagai berikut:

(1)Pratandhaning ambeg sadu, sedya nggayuh kautaman, mardi ring tyas tan rinasa, rasa rasaning dumadya. (2) Budi babataning kayun, yayah satu lan rimbagan, ginulang gelanging cipta, tancepe ingkang sinedya. (3) Winawas aywa kaliru, rubèddanè jim prayangan, angrencana sedya nira, murih wurunging kalakyan...(Martopangrawit, 1988).

Berdasarkan kutipan di atas tampak bahwa tidak satu kata pun yang secara eksplisit mengandung pengertian tentang keselamatan. Namun demikian, seandainya pemahaman keselamatan di sini diambil dari makna cakepan secara keseluruhan, yang pada hakekatnya berisikan tentang petuah kebaikan, hal itu tentu tidak dapat dijadikan pedoman. Hal tersebut dikarenakan cakepan Salisir dan cakepan Salisir Puspagiwang juga digunakan untuk sindhenan atau pun gerongan pada gending lain; dan gending tersebut tidak menjadi Ladrang Slamet atau dikatakan sebagai gending untuk permohonan do'a keselamatan. Artinya bahwa yang dimaknai sebagai do'a keselamatan pada Ladrang Slamet bukan terletak pada cakepan gerongan atau pun sindhenan, melainkan pada nama dan gending itu sendiri.

Sebagaimana ladrang pada umumnya, Ladrang Slamet terdiri dari balungan gending, vokal sindhenan dan vokal gerongan. Dengan demikian apabila merujuk pada asumsi di atas maka letak dari do'a keselamatan dalam Ladrang Slamet adalah pada nada-nada yang disusun sedemikian rupa dalam sebuah bentuk ladrang. Hal ini sesuai dengan pendapat (Donder, 2005) bahwa nada-nada dalam gamelan adalah suara-suara ritual atau suara-suara magis, karena setiap bilah gamelan melambangkan nyasa atau simbol dari salah satu istha dewata yang bereaksi (menanggapi) bunyi gamelan tersebut. (Donder, 2005). Lebih lanjut Donder menjelaskan sebagai berikut:

Esensi filosofis dari bunyi gamelan yang dipersembahkan dalam ritual adalah bahwa setiap vibrasi gelombang bunyi yang dihasilkan oleh setiap bilah daun gamelan adalah sebuah mantram atau suara puja yang tepat menuju kepada salah satu istha dewata (Donder, 2005).

Keterangan di atas menunjukkan bahwa makna Ladrang Slamet tidaklah terletak pada satu nada saja melainkan pada keseluruhan nada-nada yang digunakan beserta sistem relasinya. Hal ini disebabkan karena sebuah gending merupakan rangkaian bunyi-bunyi nada yang tersusun menjadi bangunan yang utuh dan menjadi sebuah gending yang kemudian dimaknai (bandingkan dengan Wahyudi, 2012: 24). Dengan demikian, dapat dimungkinkan bahwa struktur balungan pembentuk gending tersebut memiliki makna tertentu yang diaktualisasikan melalui sistem simbol. Artinya bahwa nada dalam karawitan yang menggunakan simbol bilangan, bukan semata-mata angka sebagai penanda nama nada, melainkan memiliki makna yang tersembunyi dibaliknya. Maka artikel ini berfokus pada mengkaji pertanyaan, "Do'a keselamatan yang seperti apakah yang diungkapkan Ladrang Slamet?”.

Berpijak dari pertanyaan di atas maka penjelasan dalam artikel ini merupakan kajian tekstual yang berorientasi pada telaah terhadap sistem relasi atas nada-nada yang terdapat dalam Ladrang Slamet secara utuh. Ladrang Slamet sebagai satu kesatuan yang utuh sebuah gending dalam analisis ini akan diurai menjadi level-level yang lebih kecil untuk memahami makna hasil dari sistem relasi nada-nadanya.

Mengacu pada pemahaman dalam karawitan mengenai struktur padhang-ulihan bertingkat 
(Martopangrawit, 1975), maka struktur balungan pembentuk Ladrang Slamet diurai menjadi dua bagian, yakni ulihan umpak dan ulihan ngelik. Umpak dan ngelik tersebut diurai lagi menjadi kenong, masing-masing kenong diurai lagi menjadi kethuk. Fenomena tersebut dapat dianalogikan dengan fenomena kebahasaan. Berpijak dari pemahaman yang sudah berlaku dalam dunia karawitan mengenai kalimat lagu yang dipahami sebagai satu kenongan, setiap kalimat lagu dapat dibagi lagi menjadi level yang lebih kecil yaitu kethuk yang terdiri dari padhang-ulihan, maka dapat dikatakan satu ulihan gongan setara dengan alinea. Dengan demikian satu gending setara dengan bab. Oleh karena itu, penjabarannya adalah dua alinea, masing-masing alinea terdiri dari empat kalimat, masing-masing kalimat terdiri dari dua frase. Pembagian-pembagian level ini untuk memudahkan dalam rangka memaknai relasi-relasi antar nada dalam keseluruhan Ladrang Slamet secara utuh.

Berdasarkan penjelasan mengenai struktur balungan gending dalam Ladrang Slamet laras slendro pathet manyura di atas, selanjutnya diperoleh pemahaman bahwa nada sebagai unsur terkecil dalam gending merupakan sistem tanda yang membangun makna dalam gending. Berkenaan dengan nada sebagai sistem tanda, (Becker, 1979) dalam Time and Tune in Java menjelaskan bahwa sistem nada slendro pada gemelan Jawa berkaitan dengan siklus perhitungan waktu berdasarkan pasaran dina. Perhitungan waktu berdasarkan pasaran dina dalam setiap siklusnya terdiri dari wage, legi, pon, pahing dan kliwon (Becker, 1979). Lebih lanjut, pasaran dina tersebut oleh Timbul Haryono (2012) disebutkan memiliki keterkaitan dengan sistem mancapat (Haryono, 2012). Dengan demikian, pemahaman mengenai nada slendro sebagai manifestasi dari pasaran dina sebagaimana dikatakan oleh Becker tersebut, dalam analisis ini digunakan untuk memahami adanya keterkaitan antara sistem slendro gamelan Jawa dengan konsep mancapat.

Berdasarkan adanya keterkaitan antara siklus pasaran dina dengan konsep mancapat, selanjutnya Heinz Frick dalam tulisan (Dwi Nugroho, 2009) mengatakan bahwa mancapat adalah corak magis yang dijelaskan ke dalam sebuah lingkaran dengan empat penjuru arah mata angin dan tengah sebagai pusat. Orientasi empat penjuru arah mata angin tersebut menunjuk arah mata angin selatan; timur; barat; utara ((Dwi Nugroho, 2009)., lihat pula (Wardani, 9AD)., (Hasim, 2011). Lebih lanjut dalam Primbon Jawa disebutkan bahwa mancapat tidak hanya berkaitan dengan pasaran dina, tetetapi berkaitan pula dengan pancaran warna, dan dewa-dewa yang bersemayam (R. Tanaya, tanpa tahun: 7). Posisi pasaran dina dan dewadewa yang bersemayam dalam konsep mancapat dapat digambarkan pada gambar 1 disertai dengan keterangannya pada tabel 1 .

Pemahaman mengenai kedudukan bilah nada gamelan dalam setiap penjuru arah mata angin dapat dijumpai pula dalam sistem gamelan Bali, yakni konsep Pangidering Bhuwana dalam Prakempa. Sebagaimana dijelaskan oleh (Bandem, 1986) dalam bukunya yang berjudul Prakempa: Sebuah Lontar Gambelan Bali, bahwa konsep Pangidering Bhuwana merupakan konsepsi 10 arah mata angin yang terdiri dari 5 nada berlaras pelog dan 5 nada berlaras slendro. Pada masing-masing arah mata angin bersemayam para dewa sebagai

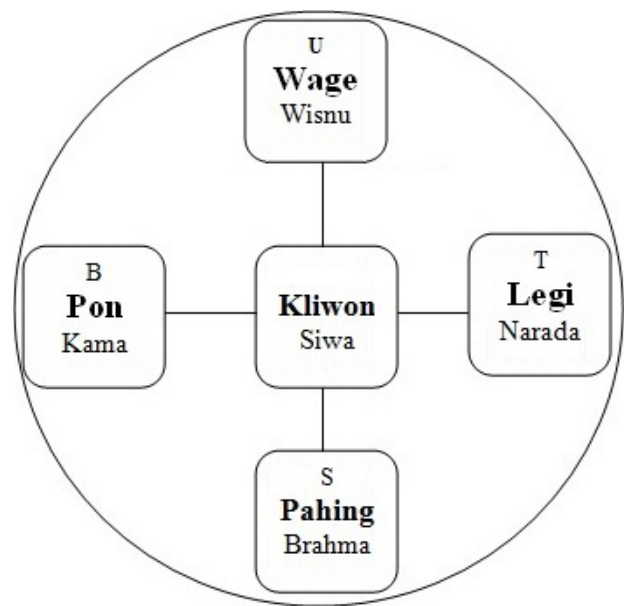

Gambar 1. Posisi pasaran dina dan dewa-dewa.

Tabel 1. Posisi pasaran dina, pancaran warna dan dewa yang bersemayam dalam konsep mancapat.

\begin{tabular}{lll}
\multicolumn{1}{c}{$\begin{array}{c}\text { Posisi } \\
\text { Mata Angin }\end{array}$} & \multicolumn{1}{c}{$\begin{array}{c}\text { Pancaran } \\
\text { Warna }\end{array}$} & \multicolumn{1}{c}{$\begin{array}{c}\text { Dewa yang } \\
\text { Bersemayam }\end{array}$} \\
\hline Barat & Kuning & Sang Hyang Kamajaya \\
Timur & Putih & Sang Hyang Narada \\
Selatan & Merah & Sang Hyang Brahma \\
Utara & Hitam & Sang Hyang Wisnu \\
Tengah & Pancawarna & Sang Hyang Siwa \\
\hline
\end{tabular}


representasi dari setiap bilah nada dalam gamelan Bali (Bandem, 1986). Gambar 2 adalah gambar konsep Pangidering Bhuwana.

Berdasarkan konsep Pangidering Bhuwana di atas, Fried B. Eiseman (2000) dalam Bali Sekala \& Niskala Volume I: Essays on Religion, Ritual, and Art menyebutkan bahwa kedudukan dewa pada setiap penjuru mata angin tersebut berkaitan dengan pasaran dina beserta pancaran warna yang terdiri dari: umanis dengan pancaran warna putih berada di penjuru mata angin timur; paing dengan pancaran warna merah berada di selatan; pon dengan pancaran warna kuning berada di barat; wage dengan pancaran warna hitam berada di utara; dan keliwon dengan panca warna berada di tengah sebagai pusat (Fried B. Eiseman, 2000).

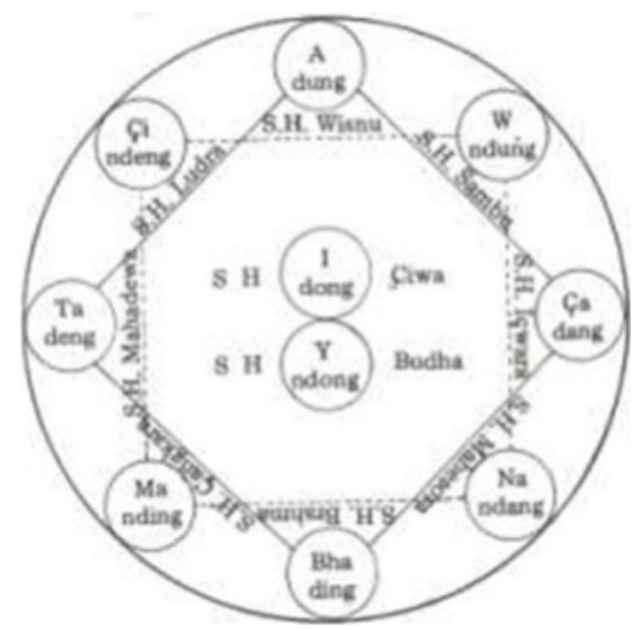

Gambar 2. Pangidering Bhuwana. (Disunting dari buku Prakempa Sebuah Lontar Gamelan Bali)

Tabel 2. Kedudukan dewa pada setiap bilah nada pelog pada gamelan Bali.

\begin{tabular}{lll}
\hline Bilah Nada & \multicolumn{1}{c}{$\begin{array}{c}\text { Dewa yang } \\
\text { Bersemayam }\end{array}$} & \multicolumn{1}{c}{$\begin{array}{c}\text { Posisi } \\
\text { Mata Angin }\end{array}$} \\
\hline Ding & Sang Hyang Brahma & Selatan \\
Dong & Sang Hyang Siwa & Tengah Atas \\
Deng & Sang Hyang Mahadewa & Barat \\
Dung & Sang Hyang Wisnu & Utara \\
Dang & Sang Hyang Iswara & Timur \\
\hline
\end{tabular}

Tabel 3. Kedudukan dewa pada setiap bilah nada slendro pada gamelan Bali.

\begin{tabular}{lll}
\hline \multicolumn{1}{c}{ Bilah Nada } & \multicolumn{1}{c}{$\begin{array}{c}\text { Dewa yang } \\
\text { Bersemayam }\end{array}$} & \multicolumn{1}{c}{$\begin{array}{c}\text { Posisi } \\
\text { Mata Angin }\end{array}$} \\
\hline Nding & Sang Hyang Sangkara & Barat Daya \\
Ndong & Sang Hyang Budha & Tengah Bawah \\
Ndeng & Sang Hyang Ludra & Barat Laut \\
Ndung & Sang Hyang Sambu & Timur Laut \\
Ndang & Sang Hyang Mahesora & Tenggara \\
\hline
\end{tabular}

Berdasarkan pemahaman mengenai posisi pasaran dina dan pancaran warna dalam kosmologi Bali di atas, ditemukan adanya kesamaan dengan posisi arah mata angin pasaran dina Jawa dalam konsep mancapat. Merujuk pada pernyataan Becker bahwa pasaran dina dalam pemahaman Jawa merupakan manifestasi dari bilah nada slendro (Becker, 1979). Maka untuk melihat makna masing-masing bilah nada slendro Jawa, dalam penelitian ini posisi bilah nada pelog dalam konsep Pangidering Bhwwana akan dipinjam untuk selanjutnya diterapkan dalam konsep mancapat. $\mathrm{Hal}$ ini didasarkan pada kesamaan posisi pasaran dina dan posisi dewa pada penjuru mata angin selatan, utara, barat, dan timur. Selanjutnya untuk memahami Ladrang Slamet laras slendro Jawa dalam penelitian ini akan digunakan konsep kedudukan dewa-dewa pada bilah gamelan sebagaimana dijelaskan dalam konsep mancapat. Dengan demikian kedudukan dewa dalam setiap bilah nada slendro Jawa dapat digambarkan pada gambar 3.

Relasi-relasi dewa berdasarkan konsep mancapat di atas dalam konsep karawitan Jawa akan dilihat berdasarkan struktur gending yang meliputi; kempyang, kethuk, kenong, kempul dan gong.

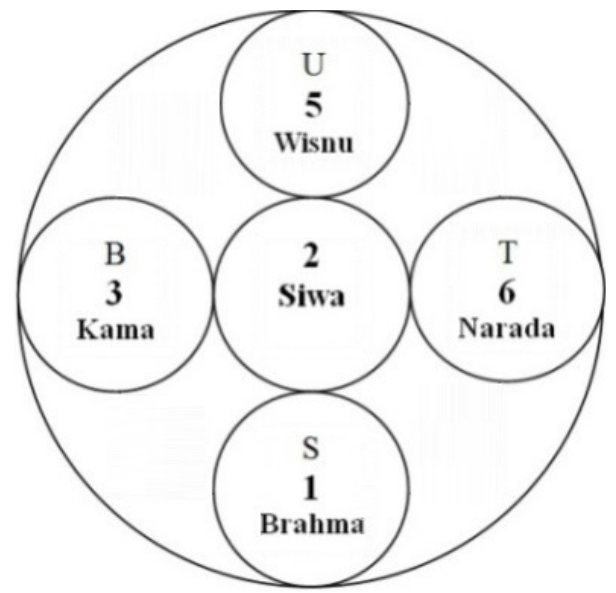

Gambar 3. Pangidering Bhuwana. (Disunting dari buku Prakempa Sebuah Lontar Gamelan Bali)

Tabel 4. Kedudukan dewa pada bilah nada slendro Jawa dalam konsep mancapat.

\begin{tabular}{lll}
\hline Bilah Nada & \multicolumn{1}{c}{$\begin{array}{c}\text { Dewa yang } \\
\text { Bersemayam }\end{array}$} & \multicolumn{1}{c}{$\begin{array}{c}\text { Posisi } \\
\text { Mata Angin }\end{array}$} \\
\hline Barang (1) & Sang Hyang Brahma & Selatan \\
Jangga (2) & Sang Hyang Siwa & Tengah \\
Dhadha (3) & Sang Hyang Kamajaya & Barat \\
Lima (5) & Sang Hyang Wisnu & Utara \\
Nem (6) & Sang Hyang Narada & Timur \\
\hline
\end{tabular}


Melalui konsep padhang-ulihan bertingkat itulah akan ditemukan relasi-relasi dewa yang digunakan untuk membangun makna dalam Ladrang Slamet laras slendro pathet Manyura.

\section{Struktur Padhang-Ulihan dalam Ladrang Slamet Laras Slendro Pathet Manyura}

Mengenai definisi tentang padhang dan ulihan dalam gending, (Martopangrawit, 1975) menjelaskan bahwa yang dimaksud dengan padhang adalah susunan nada yang belum memiliki rasa seleh. Sebaliknya, yang dimaksud dengan ulihan adalah susunan nada dalam gending yang telah memiliki rasa seleh (Martopangrawit, 1975). Selanjutnya, (Hastanto, 2009) menambahkan bahwa padhang adalah susunan nada yang memiliki rasa "mengawali", sedangan ulihan adalah susunan nada yang memiliki rasa "mengakhiri". Berdasarkan pengertian mengenai padhang-ulihan tersebut, maka dapat diketahui bahwa padhangulihan dalam gending adalah unsur pokok yang membentuk kalimat lagu gending. Sementara (Martopangrawit, 1975) menyebutkan bahwa setiap gending memiliki susunan padhang-ulihan yang bertingkat. Dikatakan demikian karena setiap gending dibangun oleh unsur terkecil (nada) yang membangun sebuah struktur baru. Struktur-struktur baru tersebut selanjutnya saling berelasi dan membangun struktur yang lebih besar, sehingga terbentuk struktur akhir yang disebut dengan gending. Dengan demikian, relasi padhang-ulihan di dalam gending tidak hanya terdapat dalam sebuah kalimat lagu yang ditandai oleh tabuhan kenong dan/atau gong, melainkan relasi padhang-ulihan gending terdapat pula pada struktur padhang-ulihan terkecil hingga struktur padhang-ulihan terbesar dalam gending sebagaimana diuraikan oleh Martopangrawit.

Berpijak pada pemahaman mengenai struktur padhang-ulihan bertingkat di atas, selanjutnya gatra sebagai satuan terkecil dari sruktur padhang-ulihan akan diurai berdasarkan kedudukannya dalam gending. Secara konvensional gatra dipahami sebagai satuan terkecil sebuah gending yang tersusun dari empat balungan (Supanggah, 2009). Sindusawarna dalam tulisan (Supanggah, 2009) menjelaskan kedudukan masing-masing balungan dalam sebuah gatra sebagai berikut:

'ding kecil'untuk sabetan balungan pertama (A), 'dong kecil' untuk sabetan balungan kedua (B), 'ding besar' untuk sabetan balungan ketiga (C), 'dong besar' untuk sabetan balungan keempat (D) (Supanggah, 2009)

Disarikan dari pandangan Sindusawarna di atas, Supanggah menyebutkan bahwa setiap balungan sebagai unsur dari gatra memiliki fungsi atau kedudukan yang berbeda-beda berdasarkan posisinya di dalam gatra. Lebih lanjut disebutkan bahwa:

Istilah dong yang dihadapkan dengan gending jelas menunjukkan adanya pembendaan dimensi, bobot dan/atau tingkatan kedudukan yang menempatkan dong lebih penting (tinggi, berat) dari pada ding... Sedangkan penggunaan istilah kecil dan besar yang melekat pada ding dan dong dengan sangat jelas menunjukkan adanya pemberian kedudukan/fungsi atau pembedaan hierarki fungsi/peran dari bagian-bagian gatra (Supanggah, 2009).

Dengan demikian maka relasi antar balungan dalam sebuah gatra memiliki kedudukan yang sama/sejajar dengan relasi padhang-ulihan dalam gending. Keduanya memiliki kedudukan sebagai unsur pokok yang membentuk kalimat lagu gending.

Berdasarkan pemahaman di atas, maka Ladrang Slamet sebagai satu kesatuan yang utuh sebuah gending dapat diurai menjadi level-level yang lebih kecil untuk menguraikan struktur padhang-ulihan bertingkat dalam Ladrang Slamet. Struktur balungan pembentuk Ladrang Slamet diurai menjadi dua bagian, yaitu ulihan umpak dan ulihan ngelik. Umpak dan ngelik di sini diurai lagi menjadi kenong, masing-masing kenong diurai lagi menjadi kethuk. Selanjutnya setiap gatra yang yang ditandai oleh pola tabuhan kethuk dapat diurai lagi menjadi level yang lebih kecil berdasarkan kedudukan yang dibangun oleh relasi antar balungan dalam gatra.

Berdasarkan struktur padhang-ulihan Ladrang Slamet yang telah diuraikan di atas, untuk 
memudahkan dalam menandai struktur padhangulihan dari level terkecil hingga terbesar, maka dalam analisis ini akan digunakan simbol-simbol sebagai berikut:

p' : relasi antar balungan dalam gatra yang memiliki kedudukan sebagai ding-dong kecil

p” : gatra yang memiliki kedudukan sebagai padhang dalam satu kenongan.

p" : kenongan yang memiliki kedudukan sebagai padhang dalam relasinya dengan kenongan selanjutnya dalam satu gongan.

p"” : dua kenongan yang memiliki kedudukan sebagai padhang dalam satu gongan.

p"'” : satu gongan yang memiliki kedudukan sebagai padhang dalam satu ulihan penuh Ladrang Slamet.

u' : relasi antar balungan dalam gatra yang memiliki kedudukan sebagai ding-dong besar

u” : gatra yang memiliki kedudukan sebagai ulihan dalam satu kenongan.

u” : kenongan yang memiliki kedudukan sebagai ulihan dalam relasinya dengan kenongan selanjutnya dalam satu gongan.

u"' : dua kenongan yang memiliki kedudukan sebagai ulihan dalam satu gongan.

u"'” : satu gongan yang memiliki kedudukan sebagai ulihan dalam satu ulihan penuh Ladrang Slamet.

Relasi dewa dalam penelitian ini akan dikaji berdasarkan pemahaman konsep dewa dalam (Hopkins, 1986) dan (Bhattacharji, 1970) bahwa dewa adalah spirit yang digunakan sebagai personifikasi alam untuk menjelaskan mengenai avatara (inkarnasi). Relasi dewa dalam konsep mancapat pada balungan Ladrang Slamet mulai dari struktur padhang-ulihan pada level terkecil hingga terbesar dapat digambarkan seperti berikut:

\section{Relasi Dewa dalam Konsep Mancapat pada Padhang-Ulihan Level Kethuk}

Berdasarkan struktur padhang-ulihan berlevel di atas, maka relasi dewa dalam konsep mancapat pada level terkecil dapat ditunjukkan melalui struktur padhang-ulihan balungan Ladrang Slamet pada gambar berikut:

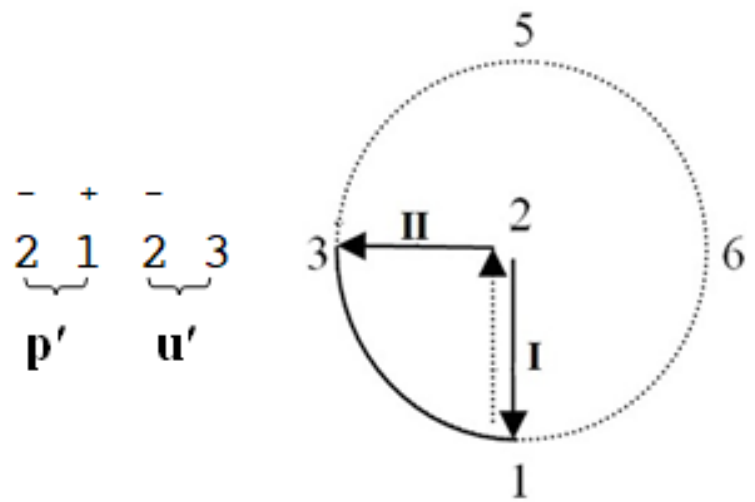

Dari struktur padhang-ulihan pada gatra pertama Ladrang Slamet di atas, diperoleh relasi 21 sebagai padhang dan 23 sebagai ulihan. Susunan nada 21 dalam konsep mancapat menunjukkan relasi antara Siwa (2) dan Brahma (1), pergerakan keduanya ditunjukan oleh panah I. Bhattacharji (1970) dalam The Indian Theoghony: A comparative study of Indian Mythology From The Vedas to The Puranas menyebutkan bahwa relasi antara Siwa dan Brahma menghasilkan Siwa sebagai Mahakala (penguasa waktu) yang sudah mengalahkan atau pun menguasai aspek Agni (api) pada Brahma dan Siwa (sebagai Prajapati) (Bhattacharji, 1970).

Sedangkan 23 dalam konsep mancapat menunjukkan relasi antara Siwa (2) dan Kama (3), pergerakan keduanya sebagai ulihan pada level kethuk ditunjukkan oleh panah II. Eiseman (2000) menjelaskan bahwa Kama diartikan sebagai desire (Fried B. Eiseman, 2000). Selanjutnya dalam hubungan relasi Siwa dengan Kama, Battacharji (1970) menyebutkan bahwa Kama dalam diri Siwa merupakan manifestasi cinta dan kesuburan, maka relasi antara Kama dan Siwa menghasilkan the mother goddess (Dewi Ibu) yang merupakan sakti Siwa sebagai Dewi kesuburan, yakni Durga atau Uma Dengan demikian, relasi padhang-ulihan dalam gatra 2 123 menghasilkan penguatan eksistensi Siwa sebagai Mahakala. Hal ini disebabkan oleh karena dalam pemujaan Siwa sebagai Mahakala terjadi sebagaimana dalam konsep lingga-yoni. Eksistensi Siwa didukung oleh saktinya Durga atau Uma, Siwa sebagai lingga dan Durga/Uma sebagai yoni. (Santiko, 1996) 


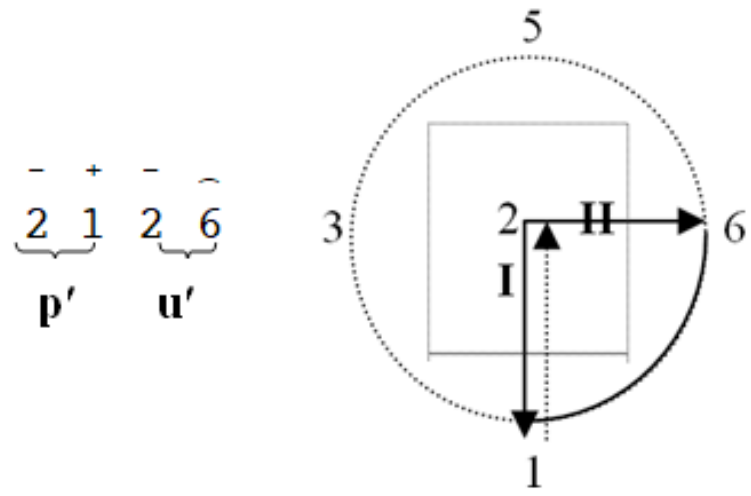

Sebagaimana dijelaskan pada keterangan gatra 2123 di atas, 21 pada gatra 212 6 berikut memiliki kapasitas sebagai padhang, sedangkan 26 sebagai ulihan. Pergerakan 2 1 sebagai relasi antara Siwa (2) dan Brahma (1) ditunjukkan oleh panah I, relasi keduanya menghasilkan Siwa sebagai Mahakala. Selanjutnya pergerakan 26 merupakan relasi antara Siwa (2) dan Narada (6) ditunjukkan oleh panah II. (Bhattacharji, 1970) dalam The Indian Theoghony: A comparative study of Indian Mythology From The Vedas to The Puranas menyebutkan bahwa Narada sebagai Maha Rsi penadaras mantra, menciptakan keindahan melalui musik puji-pujian yang dilantunkan kepada Siwa. Hubungan relasi Narada dengan Siwa adalah relasi sebagai pemuja yang mengahadirkan Siwa dalam kapasitasnya sebagai Dewa Keindahan. Dengan demikian, maka keseluruhan relasi tersebut dalam gatra $2 \quad 12$ 6 menunjukkan keberadaan Siwa (Mahakala) sebagai penguat simbol pemujaan kepada Siwa.

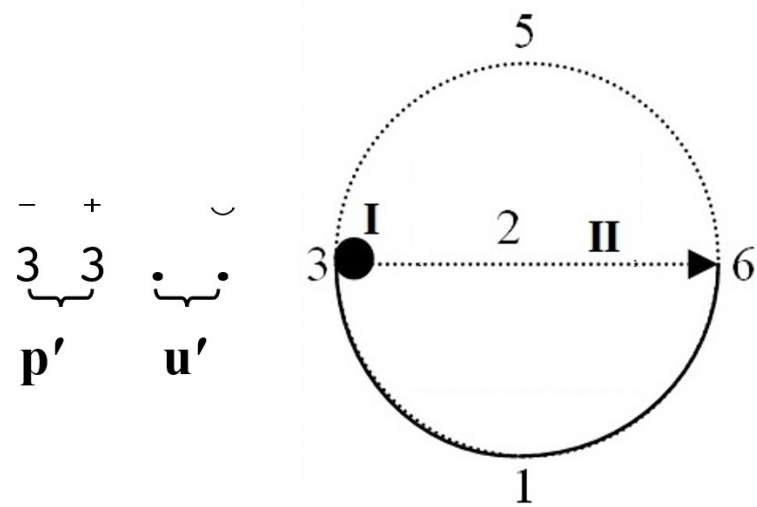

Berbeda dengan gatra sebelumnya, gatra ketiga dalam Ladrang Slamet berikut diidentifikasi sebagai balungan nggantung. Dikatakan demikian karena dalam satu gatra (empat sabetan balungan) terdapat sekurang-kurangnya dua balungan kembar berjajar secara berurutan, terutama ketika diawali oleh sabetan ganjil serta diikuti oleh sabetan genap. Selanjutnya, pin sebagai sebaten kosong merupakan kepanjangan dari balungan sebelumnya (Supanggah, 2009). Susunan nada 33 dalam struktur padhang-ulihan level kethuk memiliki kapasitas sebagai padhang, artinya susunan nada 33 tersebut dalam konsep mancapat tidak mengalami pergerakan, melainkan berhenti pada titik 3 sebagai eksistensi dari Kama (ditunjukkan oleh titik I). Sedangkan pada pin sebagai sabetan kosong memiliki kedudukan sebagai ulihan, relasinya terbangun dari pin pertama sebagai kepanjangan dari 3 dan pin kedua sebagai letak tabuhan kempul yang orientasi nadanya mengarah pada 6. Maka struktur padhang-ulihan dalam gatra ini terbangun oleh relasi 3 dan 6 . Berdasarkan konsep dewa dalam mancapat, 3 dan 6 merupakan relasi antara Kama (3) dan Narada (6). Sebagaimana diketahui bahwa Kama adalah hasrat, sedangkan Narada memiliki kapasitas sebagai pendaras mantra; dan pujia-pujian terhadap Siwa. Maka relasi keduanya menghasilkan pemusatan kekuatan laku manembah (ritual pemujaan) untuk menghadirkan sang istha dewata, yakni Siwa.

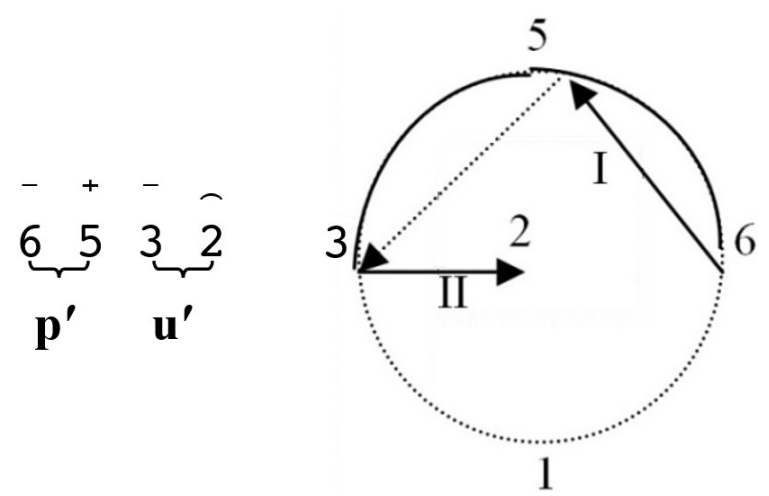

Pada gatra keempat dalam Ladrang Slamet berikut, susunan 65 diketahui sebagai padhang dan 32 sebagai ulihan. Relasi 65 dalam konsep mancapat ditunjukkan oleh panah I sebagai pergerakan relasi antara Narada (6) dan Wisnu (5). Kapasitas Narada adalah sebagai musician yang melantukan puji-pujijan kepada Siwa, serta mengabarkan pengetahuan pada Siwa; Wisnu; dan Brahma. Lebih lanjut, Bhattacharji (1970) menjelaskan bahwa relasi antara Narada 
dan Wisnu menghasilkan hubungan yang dinamakan dengan Vasudeva the eternal spirit, yang berarti Vasudeva (Wisnu) sebagai spirit keabadian (Bhattacharji, 1970).

Selanjutnya susunan nada 32 merupakan struktur ulihan, dalam konsep mancapat relasi 3 dan 2 ditunjukkan oleh relasi Kama dan Siwa. Sebagaimana telah disebutkan bahwa relasi Kama dan Siwa menghasilkan the mother goddess, yakni Durga atau Uma. Pergerakan relasi dewa pada gatra 6532 menunjukkan Vasudeva the eternal spirit dalam relasinya dengan Durga sebagai mother goddess diasosiasikan sebagai purusa, sedangkan Durga sendiri disimbolkan sebagai yoni. Dengan demikian, maka keseluruhan relasi dewa dalam struktur padhang-ulihan tersebut menghasilkan konsep lingga-yoni. Konsep lingga-yoni tersebut tidak lain adalah simbol pemujaan kepada Siwa.

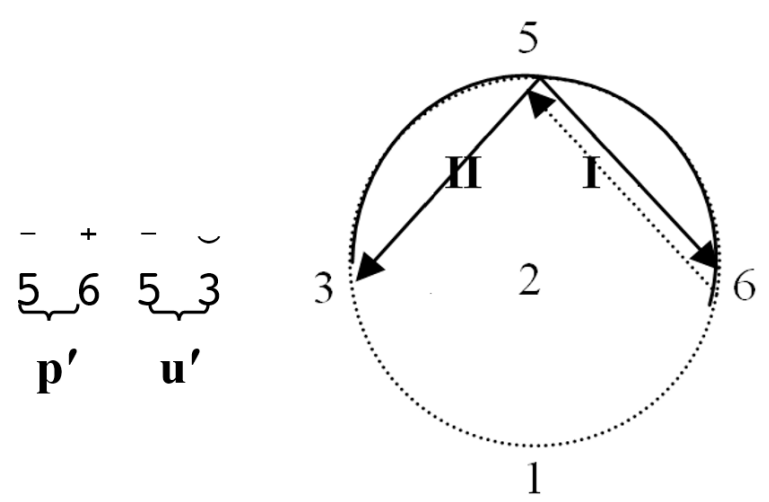

Berdasarkan konsep mancapat, susunan 5 dan 6 merupakan relasi antara Wisnu dan Narada (ditunjukan oleh panah I). Relasi keduanya diketahui menghasikan Vasudeva the eternal spirit, yakni spirit keabadian. Selanjutnya susunan 53 merupakan relasi antara Wisnu dan Kama. Battacharji (1970) menyebutkan relasi Kama dan Wisnu memunculkan eksistensi Laksmi. Laksmi diketahui sebagai sakti Wisnu sebagai dewi kecantikan, sehingga relasi anatara Laksmi dan Kama menghasilkan keindahan dan kecantikan (Bhattacharji, 1970). Keduanya dalam konsep mancapat ditunjukkan oleh pergerakan panah I sebagai relasi Wisnu dan Narada; panah II sebagai relasi Wisnu dan Kama. Keseluruhan relasi dewa dalam gatra 5 653 menghadirakan aspek Wisnu dan Laksmi, yakni keindahan yang abadi.

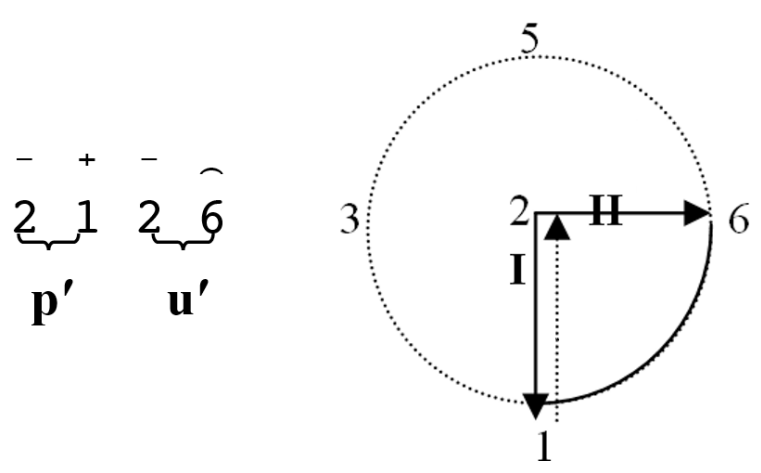

Berdasarkan uraian pada keterangan sebelumnya, dapat dilihat bahwa gatra keenam dalam Ladrang Slamet berikut merupakan pengulangan dari gatra kedua. Oleh karena itu struktur padhang-ulihan pada gatra ini memiliki kesamaan dengan gatra kedua tersebut, begitu pula relasi dewanya. Dengan demikian, maka keseluruhan hasil relasi dewa dalam gatra 212 6 menghasilkan simbol pemujaan kepada Siwa.

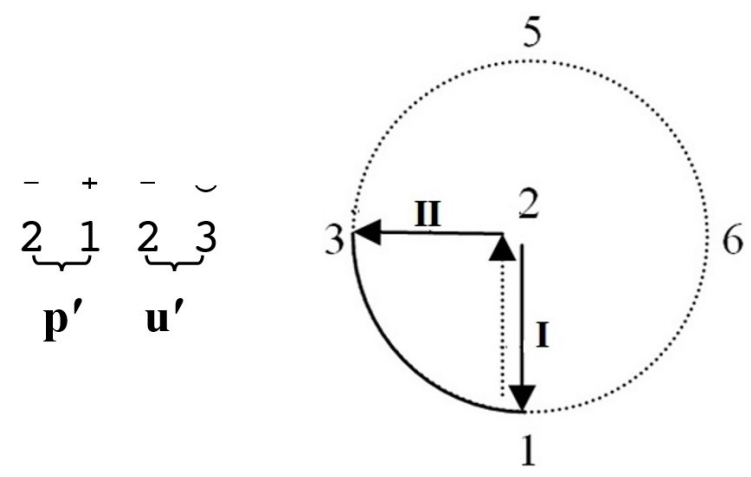

Merujuk pada keterangan dalam gatra 2 126 di atas, gatra 2123 juga merupakan pengulangan dari gatra sebelumnya, yakni pengulangan dari gatra kedua Ladrang Slamet. Dengan demikian, maka struktur padhang-ulihan dan hasil relasi dewanya sama. Pergerakan dewa pada gatra berikut adalah pergerakan dari Siwa menuju Brahma (panah I), kembali ke Siwa, kemudian menuju Kama (panah II). Keseluruhan hasil dari relasi dewa dalam gatra tersebut adalah eksistensi Siwa sebagai Mahakala.
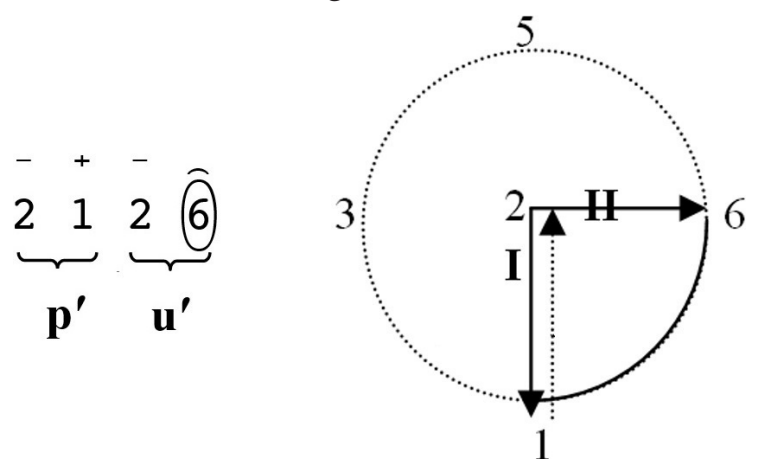
Sebagai gatra akhir dari bagian umpak, 2 126 diketahui sebagai pengulangan dari gatra kedua dan keenam. Dengan demikian relasi dewa dalam gatra tersebut menghasilkan simbol pemujaan kepada Siwa.

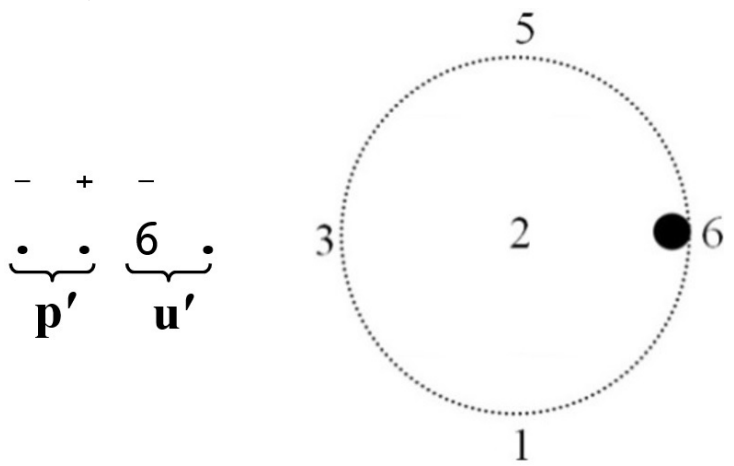

Gatra diatas diketahui sebagai balungan gantung, maka dalam konsep mancapat, dominasi nada 6 dalam gatra ini ditunjukkan oleh titik I sebagai eksistensi Narada. Dari beberapa keterangan yang disebutkan oleh (Bhattacharji, 1970) dan (Hopkins, 1986) Narada beberapa kali disebutkan sebagai pembaca mantra, pemusik, pendaras ayat suci yang memuji Siwa dan Brahma. Berdasarkan keterangan tersebut dapat disimpulkan bahwa kapasitas Narada adalah personifikasi yang digunakan untuk menjelaskan ilmu pengetahuan atau knowledge.

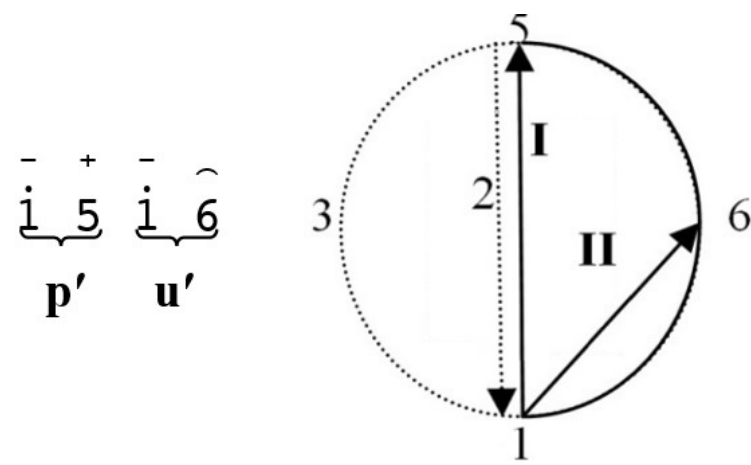

Struktur padhang-ulihan pada gatra kedua bagian ngelik Ladrang Slamet berikut terdiri dari susunan nada 15 sebagai padhang dan 16 sebagai ulihan. Berdasarkan konsep mancapat, 15 (panah I) adalah relasi antara Brahma dengan Wisnu. Selanjutnya (Bhattacharji, 1970) mengatakan bahwa relasi antara Brahma dengan Wisnu merujuk pada aspek kerajawian yang dimiliki Wisnu dalam Cakravartin. Sehingga relasi keduanya menghasilkan aspek-aspek sebagaimana terdapat dalam Cakravartin itu sendiri, yakni aspek yang mengayomi alam semesta.
Selanjutnya sebagai struktur ulihan, 16 (panah II) dalam konsep mancapat diketahui sebagai relasi Brahma dengan Narada. Relasi antara keduanya menghasilkan pengorbanan yang membebaskan dari segala macam belenggu, atau disebut dengan Citrasikhandin. Dengan demikian struktur padhang-ulihan dalam gatra1 516 menunjukkan kapasitas Brahma sebagai aspek purusa yang mengayomi alam semesta, ketika berelasi dengan Citrashikhandin maka akan menghasilkan Brahma sebagai pembebas dari kegelapan.

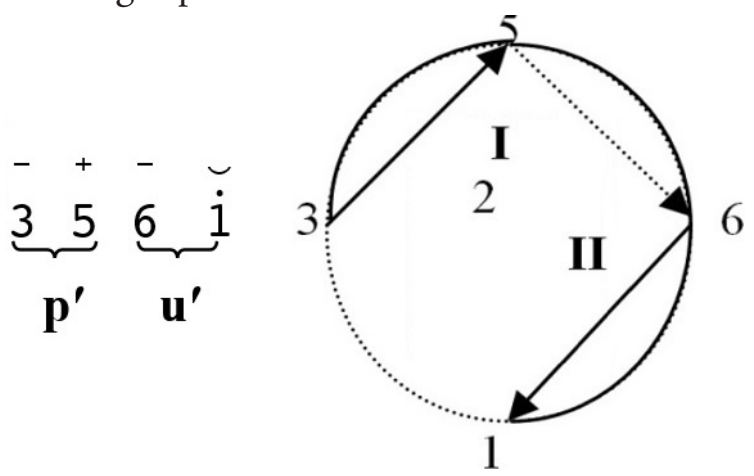

Berdasarkan konsep mancapat, 35 merupakan relasi Kama dan Wisnu. Sebagaimana dijelaskan dalam keterangan sebelumnya, bahwa relasi keduanya menghasilkan spirit keindahan dan kencantikan. Selanjutnya relasi 61 adalah relasi antara Narada dan Brahma (panah II) yang menghasilkan Citrasikhandin, yakni pengor-banan yang membebaskan dari segala macam belenggu. Dengan demikian keseluruhan relasi dalam struktur padhang-ulihan level kethuk pada gatra 3561 menghasilkan spirit keindahan yang membebaskan dari segala macam belenggu.

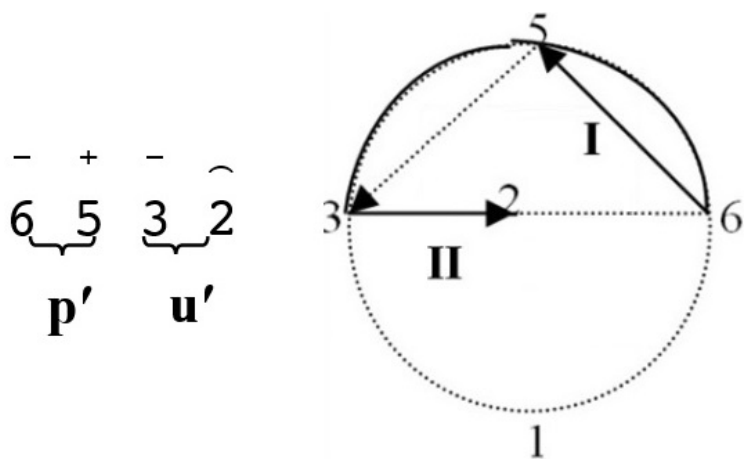

Gatra 6532 menunjukkan pengulangan dari gatra keempat bagian umpak. Dengan demikian susunan nada-nada tersebut, dalam konsep mancapat menghasilkan relasi Vasudeva 
the eternal spirit dan Durga sebagai mother goddess menghasilkan konsep lingga-yoni. Konsep lingga-yoni tersebut merupakan simbol pemujaan terhadap Siwa.

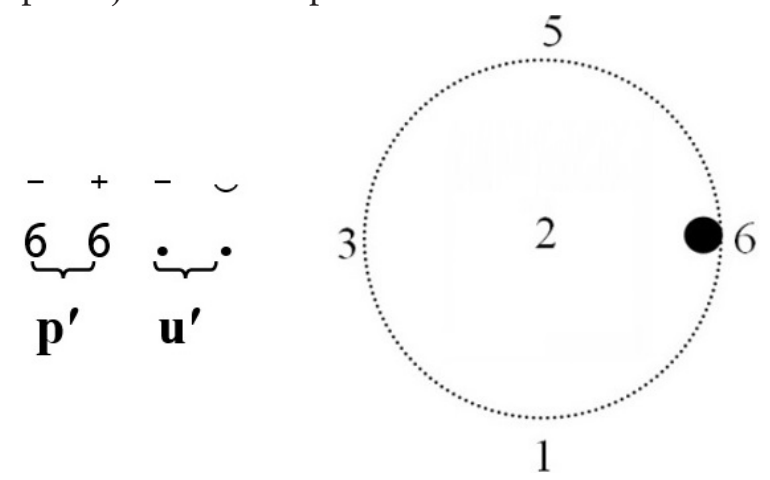

Jika merujuk dari keterangan pada gatra pertama bagian ngelik Ladrang Slamet sebelumnya, maka dapat dipahami bahwa gatra di atas merupakan gatra yang diidentifikasi sebagai balungan nggantung. Berdasarkan hal tersebut, maka konversi dewa pada gatra di atas adalah eksistensi Narada yang ditunjukkan oleh tanda titik pada posisi nada 6 sebagaimana gambar di atas. Selanjutnya, eksistensi Narada pada gatra tersebut merupakan personifikasi dari ilmu pengetahuan.

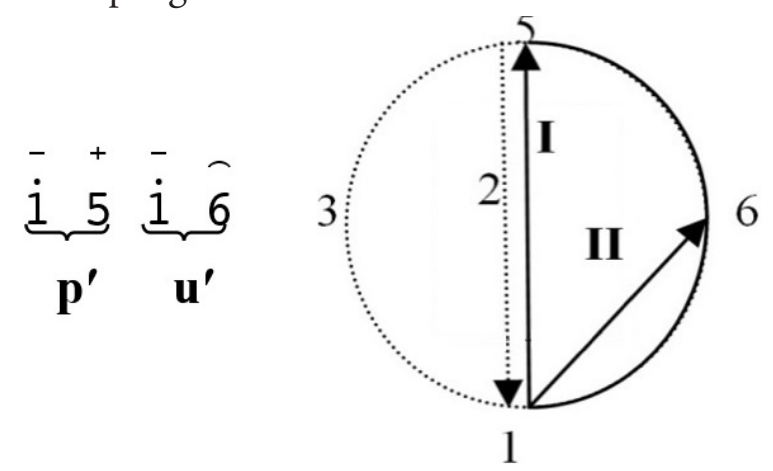

Gatra berikut merupakan pengulangan dari gatra kedua pada bagian ngelik Ladrang Slamet. Oleh karena itu, tidak ada perbedaan mengenai struktur padhang-ulihan maupun pergerakan relasi dewanya. Dengan demikian relasi dewa dalam gatra tersebut merupakan relasi Brahma-Wisnu yang diketahui menghasilkan aspek sebagai pengayom alam semesta, sedangkan relasi Brahma-Narada menghasilkan Citrasikhandin. Brahma dalam konsep penciptaan semesta bertindak sebagai purusa, sehingga ketika berelasi dengan Citrasikhandin akan menghasilkan aspek sebagai pembebas kegelapan.

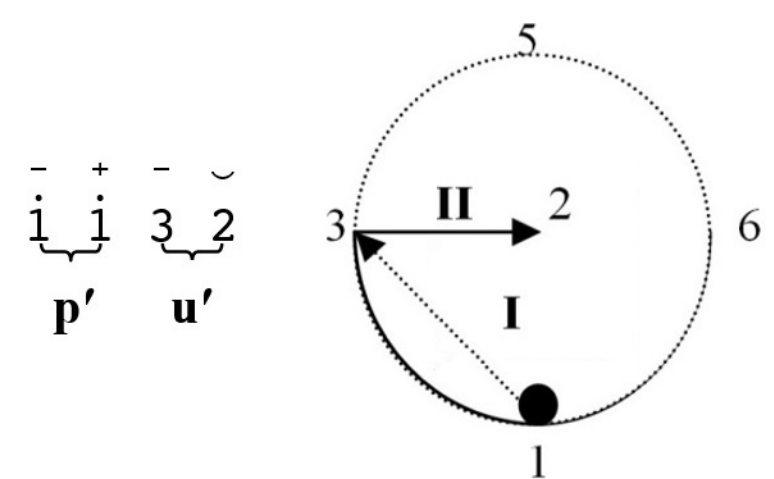

Pada gatra di atas, diperoleh keterangan bahwa susunan nada 11 sebagai balungan nggantung merupakan padhang, sedangkan 3 2 merupakan struktur ulihan. Sebagaimana diketahui bahwa 1 dalam konsep mancapat merupakan kedudukan dari Brahma, 3 adalah Kama dan 2 adalah Siwa. Susunan 1 (titik I) menunjukkan eksistensi Brahma dalam konsep penciptaan sebagai aspek purusa. Sedangkan susunan 32 (panah II) merupakan relasi antara Kama dan Siwa yang menghasilkan sakti Siwa, yakni Durga atau Uma. Dengan demikian, $\begin{array}{lllll}\text { maka keseluruhan relasi dari gatra } & 1 & 1 & 3 & 2\end{array}$ menunjukkan kapasitas Brahma dalam konsep penciptaan bertindak sebagai purusa, sehingga Brahma memberikan spirit penciptaan pada aspek kesuburan Durga. Maka hasil akhir dari relasi keduanya adalah spirit kesuburan.

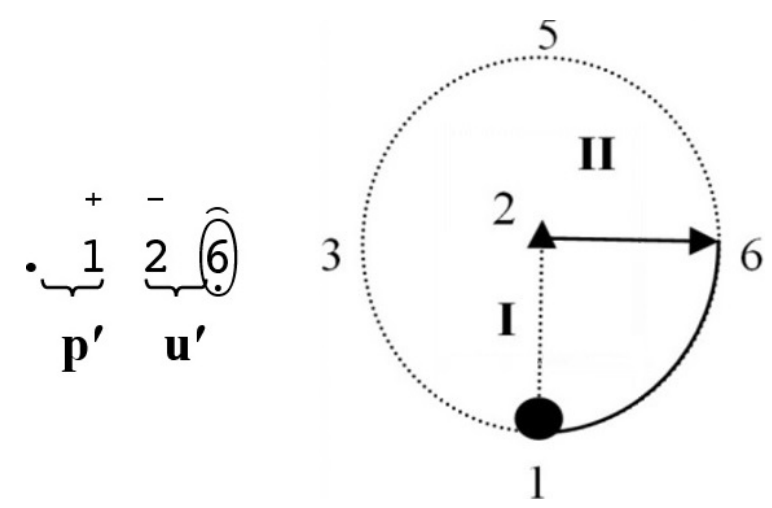

Relasi dewa pada . 1 ditunjukkan oleh eksistensi Brahma (titik I) dalam konsep penciptaan sebagai purusa. Sedangkan 26 dalam konsep mancapat menujukkan relasi antara Siwa (2) dan Narada (6) yang menghasilkan simbol pemujaan kepada Siwa. Maka keseluruhan relasi dewa dalam gatra tersebut diasosiasikan sebagai pemujaan Siwa dalam konsep lingga-yoni yang menghasilkan Siwa sebagai Mahakala. 
2. Relasi Dewa dalam Konsep Mancapat pada Padhang-Ulihan Level Kenong
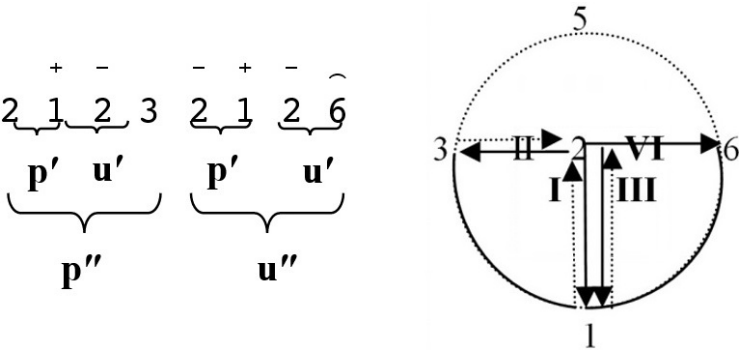

Struktur padhang-ulihan pada kenongan pertama Ladrang Slamet berikut tersusun atas gatra 2123 sebagai padhang dan gatra 2126 sebagai ulihan. Pada gatra 2123 pergerakan relasi dewa berdasarkan konsep mancapat ditunjukan oleh panah I dan II. Panah I merupakan relasi Siwa-Brahma, panah II merupakan relasi SiwaKama. Relasi-relasi dewa tersebut menghasilkan eksistensi Siwa sebagai Mahakala.

Selanjutnya, gatra 2126 dalam konsep mancapat diketahui sebagai relasi antara SiwaBrahma yang ditunjukkan oleh panah III, dan relasi Siwa-Narada yang ditunjukkan oleh panah IV. Relasi-relasi dewa dalam gatra tersebut menghasilkan simbol pemujaan kepada Siwa. Melihat bahwa hasil dari relasi kedua gatra tersebut sama-sama menghasilkan Siwa sebagai sosok yang dihadirkan. Dengan demikian, maka struktur kenongan 21232126 merupakan representasi dari simbol pemujaan Siwa.
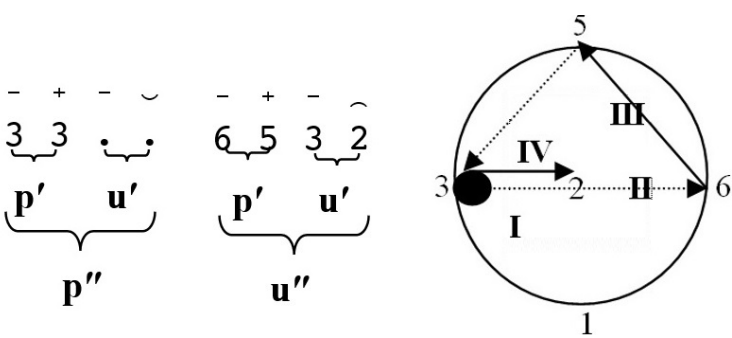

Pada struktur kenongan kedua dalam Ladrang Slamet berikut tersusun oleh gatra 3 .. sebagai padhang dan 6532 sebagai ulihan. Berdasarkan konsep mancapat, struktur padhang merupakan relasi antara Kama-Narada (panah I; II), sedangkan struktur ulihan adalah relasi yang dibangun oleh Narada-Wisnu (panah III) dan Kama-Siwa (panah IV). Relasi Kama-Narada sebagai padhang menghasilkan penghayatan dalam laku manembah. Sedangkan relasirelasi dewa sebagai strukutur ulihan tersebut menghasilkan konsep lingga-yoni sebagai pemujaan kepada Siwa. Maka, relasi dewa dalam struktur kenongan tersebut menunjukkan laku manembah yang ditujukan kepada Siwa untuk menghadirkan Siwa sebagai Mahakala.
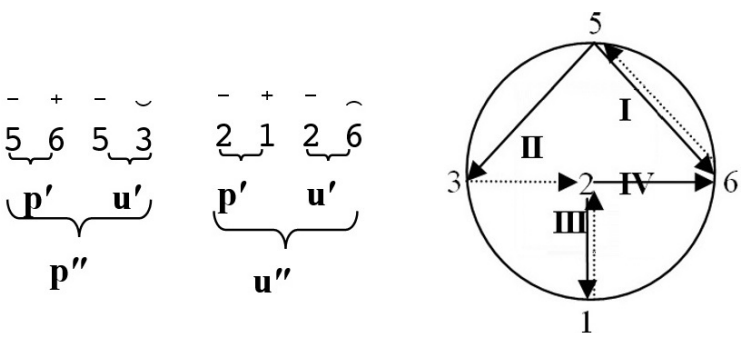

Struktur padhang-ulihan dalam kenongan di atas, terdiri dari gatra 5653 sebagai padhang (panah I, II) dan gatra 2126 sebagai ulihan (panah III, IV). Relasi dewa dalam strukutur padhang menghasilkan spirit keindahan yang abadi. Sedangan relasi dewa dalam struktur ulihan menghasilkan simbol pemujaan Siwa sebagai Mahakala. Dalam relasi berikut, spirit keindahan yang abadi dipahami sebagai aspek Siwa. Dengan demikian, maka relasi keduanya dalam struktur kenong tersebut menghasilkan Siwa sebagai Mahakala.
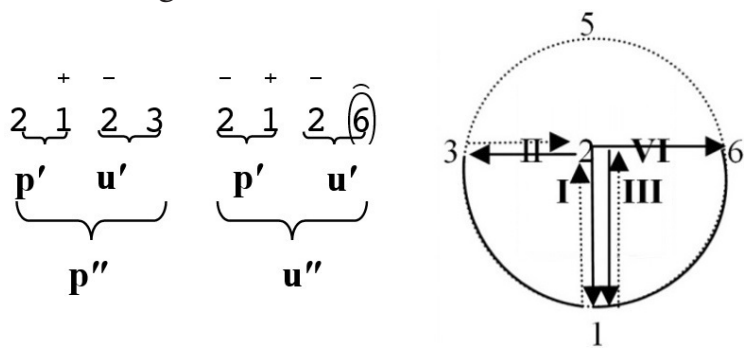

Strukur kenongan terakhir bagian umpak berikut merupakan pengulangan dari kenongan pertama. Oleh karena itu struktur padhangulihan; pergerakan relasi dewa; dan hasil relasirelasi dewanya pun sama. Dengan demikian, keseluruhan hasil relasi dewa pada struktur kenongan di atas merupakan simbol pemujaan terhadap Siwa.
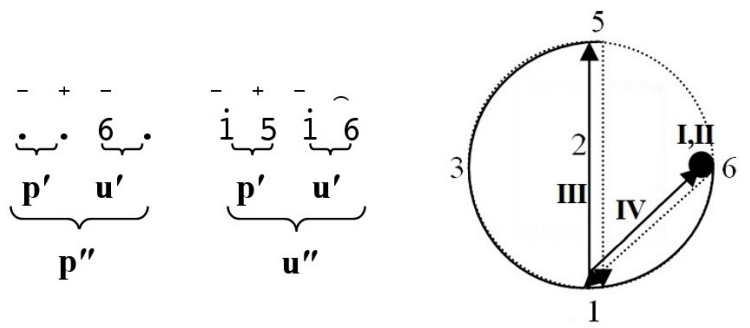

Sebagai struktur padhang (panah I, II), eksistensi Narada merupakan personifikasi 
dari ilmu pengetahuan dan puji-pujian yang dilantunkan kepada Siwa. Sedangkan relasirelasi dewa dalam struktur ulihan (panah III, IV) menegaskan aspek Brahma sebagai unsur purusa dalam konsep penciptaan yang membebaskan dari kegelapan. Dengan demikian, maka eksistensi Narada sebagai pendaras dan pemuja Siwa berelasi dengan eksistensi Brahma dalam konsep penciptaan sebagai purusa. Selanjutnya aspek kesuburan Durga menyertai relasi tersebut, sehingga keseluruhan relasi merupakan upaya penghadiran Siwa Mahakala lewat puji-pujian.
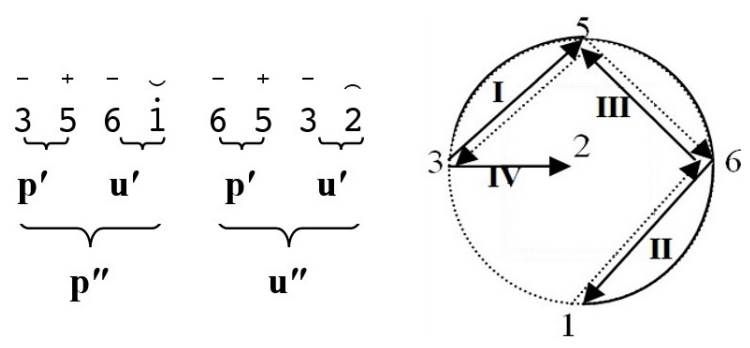

Pada struktur kenongan di atas, yang membangun struktur padhang adalah gatra 3561 dan ulihan-nya adalah gatra 653 2. Berdasarkan konsep mancapat, struktur padhang tersebut merupakan relasi KamaWisnu (panah I) dan Narada-Brahma (panah II). Keduanya menghasilkan spirit keindahan yang membebaskan dari segala macam belenggu. Sedangkan relasi-relasi dewa dalam struktur ulihan menghasilkan konsep lingga-yoni sebagai simbol pemujaan Siwa. Hasil relasi dewa dalam struktur padhang dan ulihan tersebut samasama menghasilkan aspek Siwa. Maka, relasirelasi dewa dalam struktur kenongan di atas menghasilkan Siwa sebagai Mahakala.
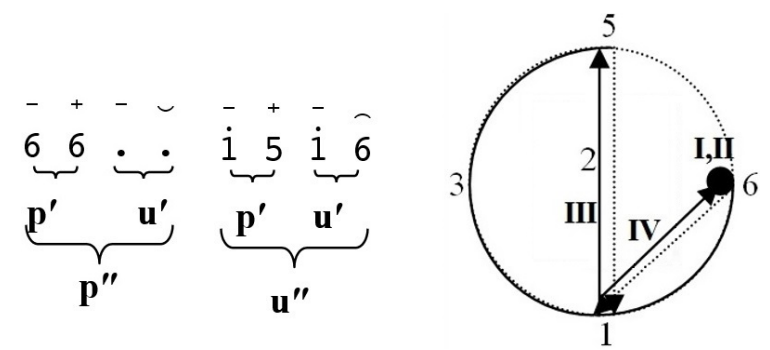

Struktur kenongan berikut memiliki kesamaan dengan struktur kenongan pertama bagian ngelik Ladrang Slamet. Dengan demikian maka dapat diketahui bahwa hasil keseluruhan relasi dewa pada struktur kenongan di atas adalah upaya penghadiran Siwa melalui puji-pujian.
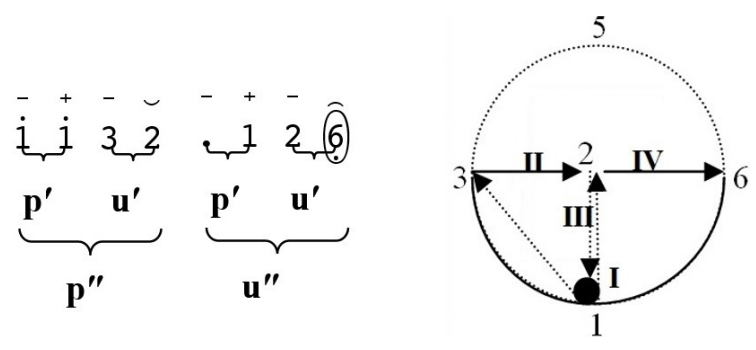

Pada struktur kenongan terakhir bagian ngelik Ladrang Slamet berikut, struktur padhang-nya diketahui sebagai relasi antara Brahma-Kama-Siwa (panah I, II). Relasi-relasi dewa tersebut menghasilkan spirit kesuburan. Sedangakan struktur ulihan-nya dibangun oleh relasi Brahma-Siwa-Narada (panah III, IV). relasi-relasi dewa dalam struktur ulihan tersebut menghasilkan konsep lingga-yoni sebagai pemujaan terhadap Siwa Mahakala. Selanjutnya, spirit kesuburan dalam relasinya dengan Siwa diidentifikasi sebagai aspek yoni, sedangkan Siwa sendiri merupakan lingga. Maka kedua relasi dewa yang dibangun oleh struktur padhang dan ulihan tersebut menghasilkan Siwa sebagai Mahakala.

\section{Relasi Dewa dalam Konsep Mancapat pada} Padhang-Ulihan Level Dua Kenongan

Struktur padhang-ulihan Ladrang Slamet pada level dua kenongan berikut merupakan kelipatan dari struktur padhang-ulihan pada level sebelumnya. Oleh karena itu, relasi-relasi dewanya terbangun oleh relasi dewa dalam struktur padhang-ulihan kethuk; dan padhangulihan kenongan. Dengan demikian, relasi dewa dalam padhang-ulihan dua kenongan dapat dijelaskan seperti berikut:

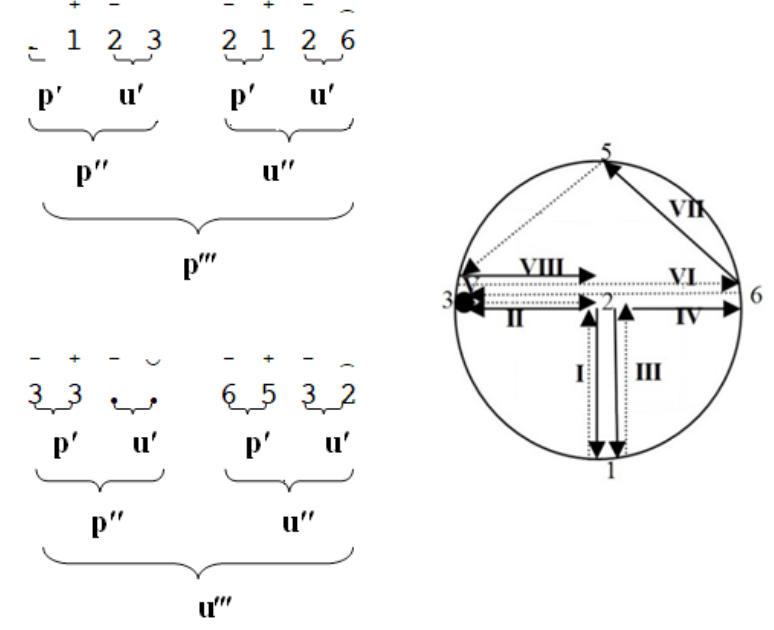


Berdasarkan konsep mancapat kalimat lagu pada kenongan pertama tersebut pergerakan dewanya ditunjukkan oleh panah I: SiwaBrahma; panah II: Siwa-Kama; panah III: SiwaBrahma; panah IV: Siwa-Narada. Keseluruhan relasi dewa dalam struktur padhang tersebut menghasilkan simbol pemujaan terhadap Siwa. Selanjutnya, struktur kenongan kedua sebagai struktur ulihan dalam konsep mancapat merupakan relasi-relasi dewa yang ditunjukkan oleh panah V: eksistensi Kama; panah VI: relasi Kama-Siwa; panah VII: Narada-Wisnu; dan panah VIII: Kama-Siwa. Relasi-relasi dewa tersebut menghasilkan Siwa sebagai Mahakala. Dengan demikian maka relasi yang dihasilkan dari struktur padhang dan struktur ulihan dalam level dua kenongan menghasilkan Siwa sebagai Mahakala.
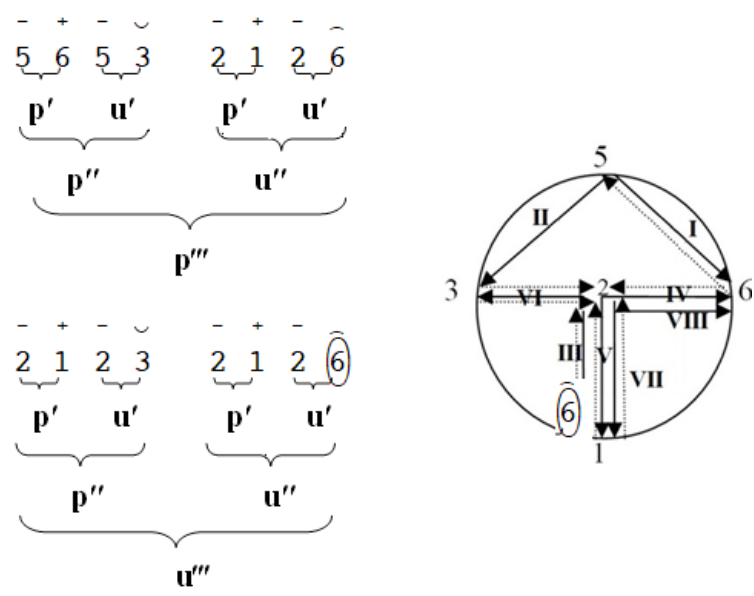

Dua kenongan terakhr dalam umpak Ladrang Slamet berikut terdiri dari susunan kalimat lagu 56532126 sebagai struktur padhang, dan kalimat lagu $\begin{array}{lllllll}2 & 1 & 2 & 3 & 2 & 1 & 2\end{array}$ 6 sebagai struktur ulihan. Relasi-relasi dewa dalam struktur padhang tersebut menghasilkan Siwa sebagai Mahakala. Selanjutnya, struktur ulihan di atas merupakan pengulangan dari kenong pertama pada umpak Ladrang Slamet. Oleh karena itu pergerakan relasi dewa dan hasil relasi-relasi dewanya sama, yakni simbol pemujaan terhadap Siwa. Merujuk pada hasil relasi dewa dalam struktur padhang dan ulihan tersebut, maka selanjutnya diperoleh relasi akhir dalam struktur padhang-ulihan level dua kenongan yang menghasilkan Siwa sebagai Mahakala.
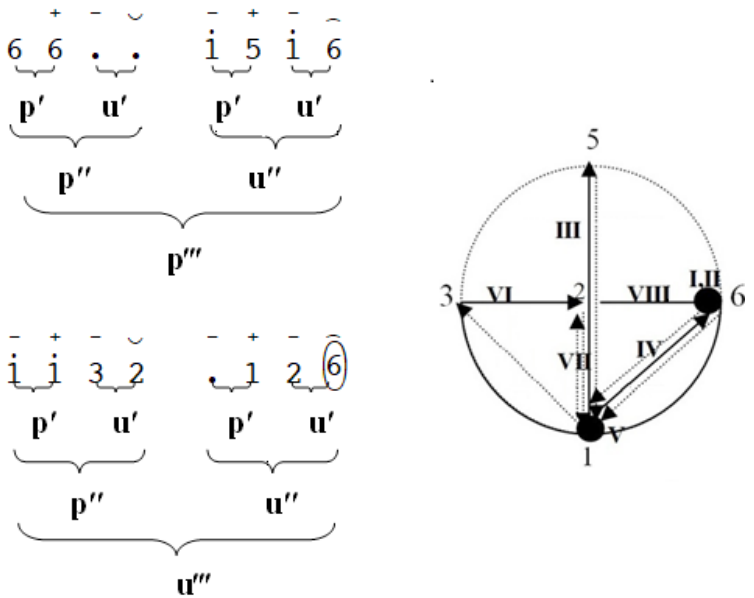

Struktur padhang-ulihan level dua kenongan berikut disusun oleh kenongan pertama sebagai padhang dan kenongan kedua sebagai ulihan. Struktur padhang tersebut dalam konsep mancapat ditunjukkan oleh pergerakan relasi dewa pada panah I, II: eksistensi Narada; panah III: relasi Brahma-Wisnu; dan panah IV: Brahma-Narada. Selanjutnya, relasi-relasi dewa tersebut merupakan representasi puji-pujian yang ditujukan kepada Siwa untuk penghadiran Siwa Mahakala. Lebih lanjut, pada struktur ulihan, pergerakan relasi dewa-dewa dalam konsep mancapat ditunjukkan oleh panah V: relasi Kama-Wisnu; panah VI: Narada-Brahma; panah VII: Narada-Wisnu dan panah VIII: Kama-Siwa. Relasi-relasi dewa dalam struktur ulihan tersebut menghasilkan Siwa sebagai Mahakala. Dengan demikian, relasi dewa dalam struktur padhang dan ulihan level dua kenongan tersebut menghasilkan Siwa sebagai Mahakala.
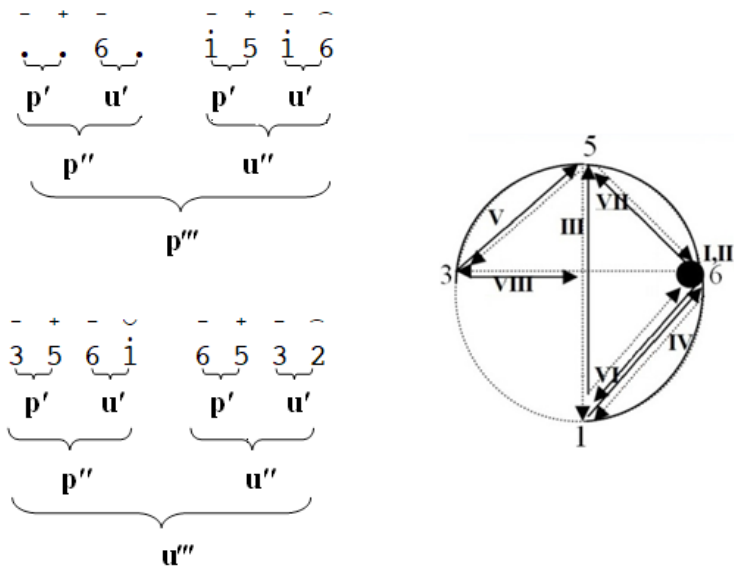

Struktur padhang-ulihan level dua kenongan pada akhir Ladrang Slamet berikut terdiri dari kenongan pertama sebagai padhang, dan kenongan kedua sebagai struktur ulihan. 
Selanjutnya dalam konsep mancapat relasirelasi dewa pada struktur padhang tersebut ditunjukkan oleh panah I, II: eksistensi Narada; panah III: relasi Brahma-Wisnu; panah IV: Brahma-Narada. Relasi-relasi dewa tersebut merupakan representasi puji-pujian yang dilantunkan kepada Siwa untuk menghadirkan Siwa sebagai Mahakala.

Selanjutnya kenongan kedua sebagai struktur ulihan diketahui merupakan relasi-relasi dewa yang ditunjukkan oleh panah V: sebagai eksistensi Brahma; panah VI: relasi Kama-Siwa; panah VII: eksistensi Brahma dan panah VIII: Siwa-Narada. Lebih lanjut, relasi-relasi dewa dalam struktur ulihan tersebut menghasilkan Siwa Mahakala. Dari kedua relasi dewa yang dihasilkan oleh struktur padhang dan ulihan di atas menunjukkan hasil yang sama, yakni Siwa sebagai Mahakala. Dengan demikian maka hasil akhir dari relasi dewa dalam struktur padhangulihan level dua kenongan tersebut adalah Siwa Mahakala.

\section{Relasi Dewa dalam Konsep Mancapat pada Padhang-Ulihan Level Gongan}

Struktur gongan bagian umpak dalam Ladrang Slamet tersebut tersusun oleh dua kenongan pertama sebagai struktur padhang; dan dua kenongan terakhir sebagai ulihan. Dalam konsep mancapat, keseluruhan relasi dewa dalam struktur padhang tersebut menghasilkan Siwa sebagai Mahakala. Selanjutnya, relasi-relasi dewa pada struktur ulihan tersebut menghasilkan Siwa sebagai Mahakala. Oleh karena struktur padhang dan ulihan sama-sama menghasilkan Siwa sebagai Mahakala, maka hasil akhir dari relasi dewa dalam strukutur gongan umpak Ladrang Slamet tersebut adalah Siwa sebagai Mahakala.

Pada struktur padhang-ulihan level gongan bagian ngelik berikut, yang teridentifikasi sebagai struktur padhang adalah dua kenongan pertama. Relasi-relasi dewa tersebut dikatahui menghasilkan Siwa sebagai Mahakala. Selanjutnya relasi dewa dalam struktur ulihan pada gongan ngelik menghasilkan Siwa sebagai Mahakala. Dengan demikian, struktur padhang-ulihan level gongan pada bagian ngelik menunjukkan relasi dewa dengan hasil yang sama, yakni Siwa sebagai Mahakala.

\section{Relasi Dewa dalam Konsep Mancapat pada Padhang-Ulihan Level Ulihan Penuh Ladrang Slamet}

Struktur padhang-ulihan pada ulihan penuh Ladrang Slamet berikut merupakan struktur padhang-ulihan level terbesar. Dalam satu ulihan penuh, Ladrang Slamet terdiri dari gongan umpak dan gongan ngelik. Struktur padhang-ulihan pada level ulihan penuh Ladrang Slamet berikut terdiri dari gongan umpak sebagai padhang dan gongan ngelik sebagai ulihan. Relasirelasi dewa dalam struktur padhang level ulihan penuh Ladrang Slamet tersebut menghasilkan Siwa sebagai Mahakala.

Selanjutnya, relasi-relasi dewa dalam struktur ulihan level ulihan penuh Ladrang Slamet tersebut menghasilkan Siwa sebagai Mahakala. Dengan melihat keseluruhan hasil dari relasi-relasi dewa dalam struktur gongan umpak dan ngelik di atas akan menghasilkan Siwa sebagai Mahakala. Dengan demikian, dapat dikatakan bahwa keseluruhan jalinan nada-nada dalam Ladrang Slamet merupakan representasi dari simbol pemujaan kepada Siwa.

\section{Penutup}

Berdasarkan keseluruhan hasil dari relasi dewa-dewa yang telah dipaparkan pada penelitian ini, dapat dipahami bahwa kapasitas Siwa mempengaruhi seluruh relasi dewa dalam Ladrang Slamet. Hubungan Siwa-Kama (barat)Narada (timur) dalam sistem dewa pada bilah nada slendro menunjukkan kapasitas Siwa yang menopang aktifitas dewa yang lain. Siwa sebagai dewa yang memberikan kerahayuan; keberuntungan; keselamatan; dan yang memberi harapan, diwujudkan melalui relasi dewa (aspek) yang lain, diantaranya Kama sebagai hasrat dan Narada yang menjelaskan serta menuntun hasrat pada pengetahuan yang benar, yakni mantra yang dilantunkan sebagai puji-pujian kepada Siwa guna menghadirkan Siwa sebagai dewa keindahan. 
Selanjutnya, hubungan Siwa-Kama-BrahmaNarada dalam hubungan relasinya menunjukkan kapasitas Siwa yang juga menopang aktifitas dewa lainnya. Narada sebagaimana disebutkan lahir dari paha Siwa ketika berelasi dengan Brahma menghasilkan Citrasikhandin. Sementara relasi Narada dengan Wisnu menghasilkan Vasudeva the eternal spirit, yakni spirit keabadian yang kemudian dihadirkan kembali melalui relasi Siwa dan Brahma yang menghasilkan Siwa sebagai Mahakala (penguasa waktu).

Merujuk pada keseluruhan hasil relasi dewa dalam Ladrang Slamet tersebut, maka dapat disimpulkan bahwa Ladrang Slamet merupakan gending pemujaan terhadap Dewa Siwa. Sebagaimana telah disebutkan di awal mengenai pemahaman masyarakat tentang penggunaan Ladrang Slamet sebagai ungkapan do'a permohonan keselamatan, dimungkinkan makna keselamatan tersebut terepresentasi melalui simbol pemujaan kepada Dewa Siwa. Namun demikian, makna keselamatan yang terkandung dalam Ladrang Slamet masih harus dibuktikan lagi melalui penelitian selanjutnya yang lebih komprehensif serta mengacu pada hubungan intertekstualitas kebudayaan Jawa.

\section{Kepustakaan}

Bandem, I. M. (1986). Prakempa: Sebuah Lontar Gambelan Bali. Denpasar: Akademi Seni Tari Indonesia.

Becker, J. (1979). "Time and Tune In Java" in A. L. Becker and Aram A. Yengoyan, Editor. The Imagination Of Reality: Essays In Southeast Asian Coherence System. Norwood, New Jersey: Ablex Publishing Corporation.

Bhattacharji, S. (1970). The Indian Theoghony: A Comparative Study of Indian Mythology from The Vedas to The Puranas. New York: Cambridge Unyversity Press.

Donder, I. K. (2005). Esensi bunyi gamelan dalam prosesi ritual Hindu: perspektiffilosofis-teologis, psikologis, sosiologis, dan sains. Paramita.

Dwi Nugroho, M. (2009). Modul Pengantar Interior Bangunan Jawa". Yogyakarta: Program Studi S-1 Desain Interior ISI Yogyakarta.

Fried B. Eiseman, J. (2000). Bali Sekala \& Niskala Volume I: Essays on Religion, Ritual, and Art. Jakarta: Java Books.

Haryono, T. (2012). Masyarakat Jawa Kuna dan Lingkungannya pada Masa Borobudur" dalam 100 Tahun Pemugaran Candi Borobudur: Trilogi I: Menyelamatkan Kembali Candi Borobudur. Magelang: Balai Konservasi Peninggalan Borobudur.

Hasim, M. (2011). Makna Arsitektur Masjid Pakualaman dalam Tinjauan Kosmologi Jawa. Analisa, 18(2).

Hastanto, S. (2009). Konsep Pathet, Dalam Karawitan Jawa. Program Pascasarjana bekerjasama dengan ISI Press, Surakarta.

Hopkins, E. W. (1986). Epic Mythology. Delhi, Varanasi, Padna, Madras: Motilal Banarsidass.

Martopangrawit, R. 1. (1975). Pengetahuan Karawitan Jilid I. Akademi Seni Karawitan Indonesia, Surakarta.

Martopangrawit, R. 1. (1988). Dibuang Sayang Lagu dan Cakepan Gerongan Gending-gending Gaya Surakarta. Surakarta: Akademi Seni Karawitan Indonesia.

Santiko, H. (1996). Bhatari Durga di Jawa: Sebuah Tinjauan Sejarah". Majalah Cempala.

Saptono. (2005). Upacara Tingalan Jumenengan dan Pernikahan Agung di Keraton Kasunanan Surakarta. Resital Jurnal Seni Pertunjukan, 6(2).

Supanggah, R. (2009). Bothekan Karawitan II: Garap. Program Pascasarjana bekerja sama dengan ISI Press, Surakarta.

Suyoto, Timbul Haryono, S. H. (2015). Estetika Bawa dalam Karawitan Gaya Surakarta. Resital Jurnal Seni Pertunjukan, 16(1).

Wardani, L. K. et. al. (9AD). Gaya Seni HinduJawa pada Tata Ruang Keraton Yogyakarta. Dimensi Interior, 2. 